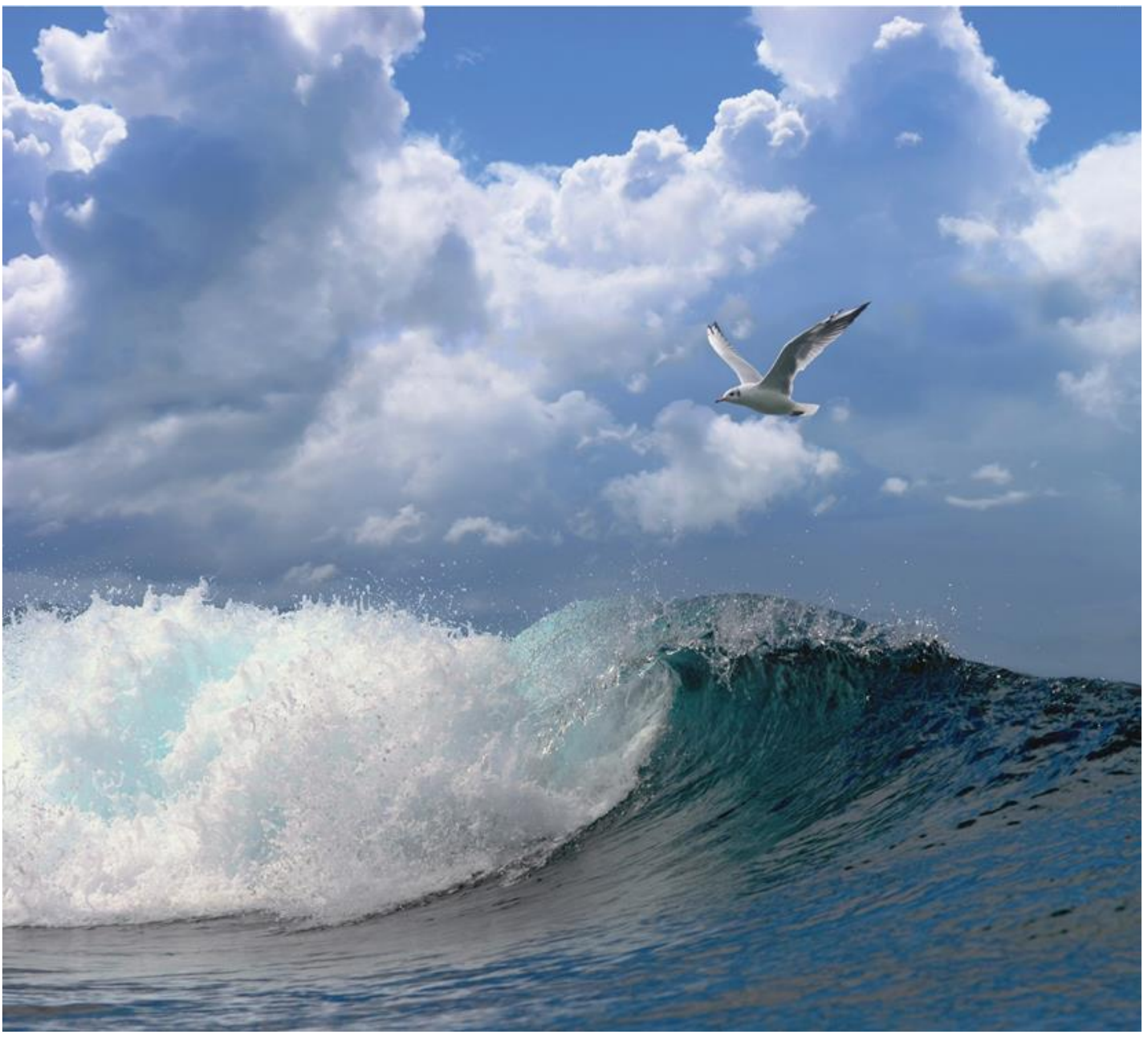

\title{
Visserij-intensiteit in en rondom het Prinses Amalia Wind Park
}




\section{Visserij-intensiteit in en rondom het Prinses Amalia Wind Park}

Auteur(s): $\quad$ Marcel Machiels

Publicatiedatum: 12 december 2017

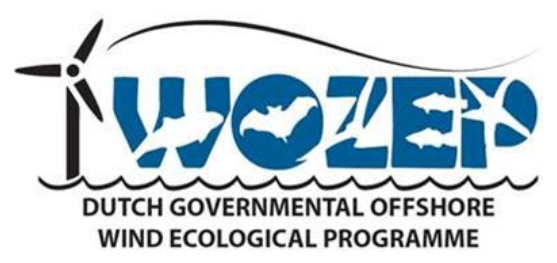


Marcel Machiels, 2017. Visserij-intensiteit in en rondom het Prinses Amalia Wind Park; Wageningen Marine Research Wageningen UR (University \& Research centre), Wageningen Marine Research rapport C091/17, 23 blz.

Opdrachtgever: Rijkswaterstaat Zee en Delta

T.a.v. Maarten de Jong

Postbus 556

3000 AN Rotterdam

Dit rapport is gratis te downloaden van https://doi.org/10.18174/428217

Wageningen Marine Research verstrekt geen gedrukte exemplaren van rapporten.

Wageningen Marine Research Wageningen UR is ISO 9001:2008 gecertificeerd.

(c) 2017 Wageningen Marine Research Wageningen UR

Wageningen Marine Research, onderdeel van Stichting Wageningen Research KvK nr. 09098104,

IMARES BTW nr. NL 8113.83.696.B16

Code BIC/SWIFT address: RABONL2U IBAN code: NL 73 RABO 0373599285
De Directie van Wageningen Marine Research is niet aansprakelijk voor gevolgschade, noch voor schade welke voortvloeit uit toepassingen van de resultaten van werkzaamheden of andere gegevens verkregen van Wageningen Marine Research opdrachtgever vrijwaart Wageningen Marine Research van aanspraken van derden in verband met deze toepassing.

Dit rapport is vervaardigd op verzoek van de opdrachtgever hierboven aangegeven en is zijn eigendom. Niets uit dit rapport mag weergegeven en/of gepubliceerd worden, gefotokopieerd of op enige andere manier gebruikt worden zonder schriftelijke toestemming van de opdrachtgever. 


\section{Inhoud}

Samenvatting

$1 \quad$ Inleiding $\quad 5$

2 Methoden $\quad 6$

$\begin{array}{llr}3 & \text { Resultaten } & 7\end{array}$

4 Discussie $\quad 9$

$5 \quad$ Bijlagen $r$

$\begin{array}{llr}\text { Kwaliteitsborging } & 20\end{array}$

$\begin{array}{lr}\text { Referenties } & \mathbf{2 1}\end{array}$

$\begin{array}{lr}\text { Verantwoording } & 22\end{array}$ 


\section{Samenvatting}

Het intensiteit van de bodemberoerende Nederlandse visserij vanaf 2002 is gekwantificeerd door middel van kaarten met de gemiddelde bodemberoering t. o.v de gebiedsoppervlakte van vakken (500 bij 500 meter) in rond het Prinses Amalia Wind Park voor de kust bij IJ muiden. 


\section{$1 \quad$ Inleiding}

Dit rapport is geschreven in opdracht van Rijkswaterstaat (RWS). Wageningen Marine Research is gevraagd om kaarten te leveren van de visserij-intensiteit van alle bodem beroerende (Nederlandse) visserijschepen in en rondom het Prinses Amalia Wind Park (PAWP) vanaf 2002. Het Prinses Amalia Wind Park (PAWP of Q7), ligt 23 km buiten de kust. De constructieperiode start in oktober 2006 en eindigt in november 2007. Het windpark is operationeel vanaf juni 2008.

RWS monitort bodemdieren door bodemschaafmonsters te nemen in en rond het gebied op verschillende tijdstippen voor en na de constructie periode [2002, 20132015 en 2017]. Voor de beoordeling van de resultaten van deze bemonstering is het van belang om de ruimtelijke dynamiek van de visserij-intensiteit in het gebied te kennen. WMR heeft kaarten gemaakt om inzichtelijk te maken welke gebieden, wanneer en met welke intensiteit bevist worden. Tevens is onderzocht wanneer in de nabijheid van de meetpunten gevist werd gedurende twee jaar voorafgaand aan het tijdstip van de metingen. 


\section{Methoden}

Om tot beantwoording van deze vraag te komen, hebben wij de volgende activiteiten uitgevoerd: Voor de bodemberoerende tuigcategorieën [boomkor (incl puls, sumwing en garnaal), bordentrawl (otterboard en twin-trawl), sleepnet (handmatig en mechanisch) en zegen (Danish seine, Scottisch seine / flyshoot)] zijn de beschikbare logboek- en VMS gegevens geselecteerd voor de jaren 2002 tot en met (april) 2017.

De VMS-plicht geldt sinds 2005 voor schepen vanaf 15 meter en vanaf 2012 voor alle schepen groter dan 12 meter. Op regelmatige tijden wordt er een VMS signaal (ping) naar een satelliet gestuurd, waarbij de scheeps-ID, tijdstip, geografische positie, snelheid en richting van een vaartuig wordt opgeslagen. Op basis van scheeps-ID, tijd en positie kunnen deze VMS gegevens worden gekoppeld aan logboekregistraties. In logboeken wordt dagelijks bijgehouden wat een visser gedurende een reis

\section{PAWP en Omstreken}

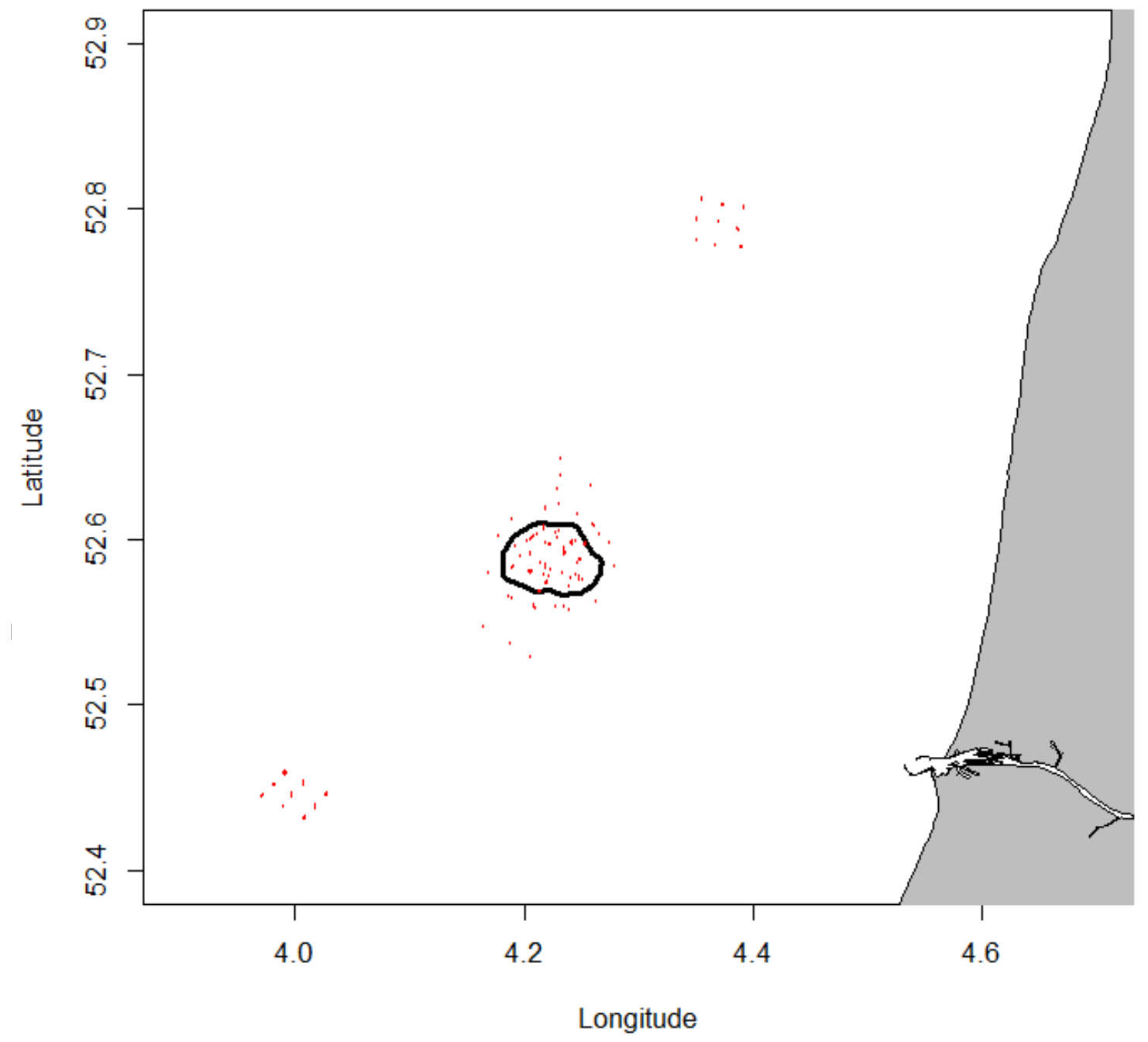




\section{Resultaten}

Een kaart van het studiegebied met het windpark en bodemschaafmonsterpunten (Figuur 1) De analyses vinden plaats op basis van alle VMS en logboek gegevens die zich binnen het gebied op deze kaart

\section{PAWP en Omstreken}

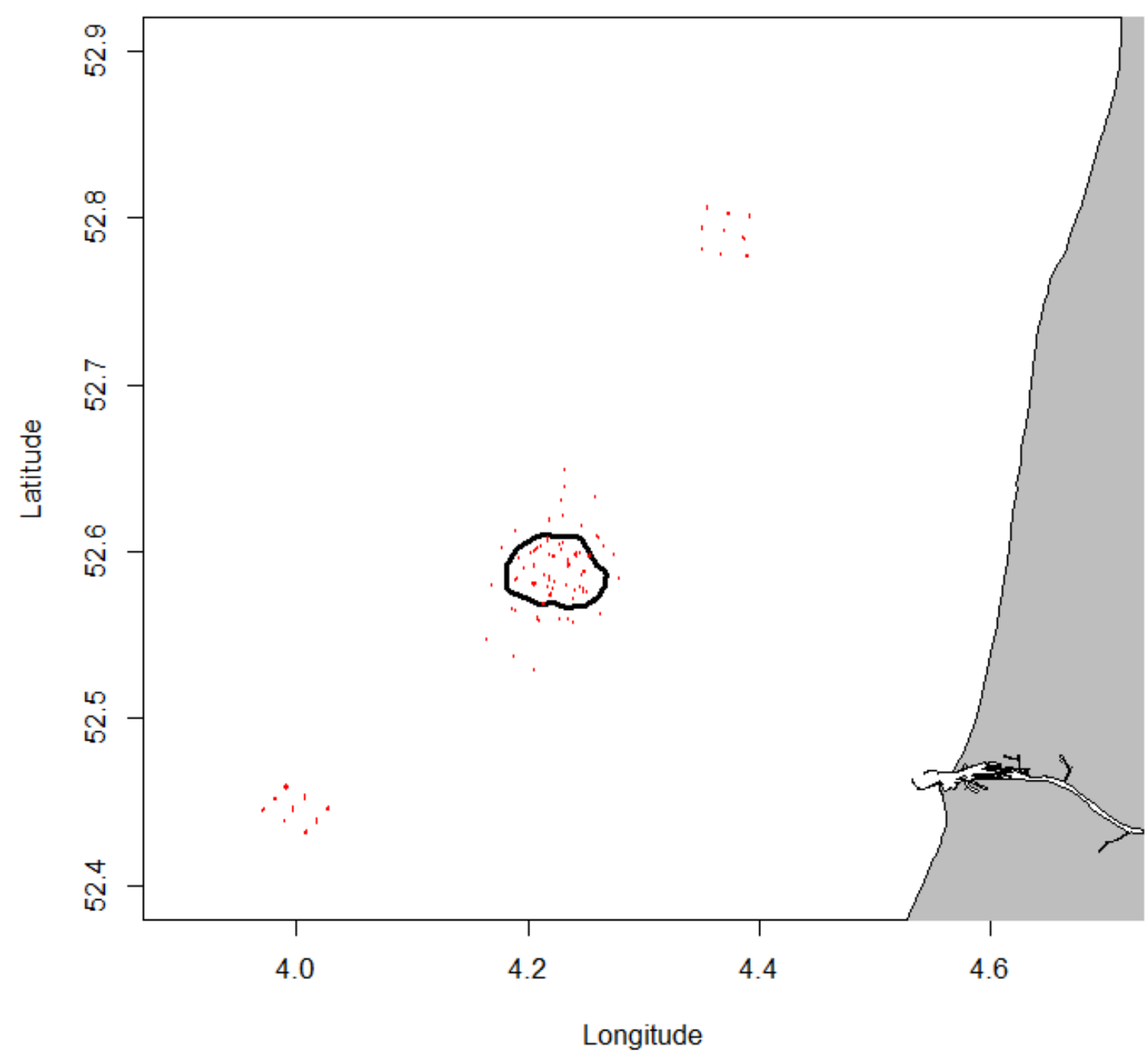

Figuur 1. De ligging van het PAWP in de Noordzee voor de kust van IJ muiden (NH) en de locatie van de meetpunten bodemschaafmonsters (rood.

De visserij-intensiteit, uitgedrukt als visfrequentie per vak (Swept-area-ratio) van $0.25 \mathrm{~km} 2$ per jaar is in Bijlage 1 geplot per 2 of 3 jaar. De visfrequentie is ingedeeld in 8 klassen, van 0 (= niet bevist, wit) tot $>5$ (een vak van $0.25 \mathrm{~km}^{2}$ wordt meer dan 5 keer bevist per jaar: het bevist oppervlak van dat vak is dan groter dan $1.25 \mathrm{~km}^{2}$, donker rood) De waarden van de tussenliggende klassen staan in de legenda van de figuren (rechtsboven). De grijze stippen laten, in verband met bescherming van persoonsgegevens, een beperkt aantal willekeurig geselecteerde van VMS posities zien (ongeveer $10 \%$ van het totaal) 
De visserij-intensiteit, uitgedrukt als visfrequentie per vak (Swept-area-ratio) van $0.25 \mathrm{~km} 2$ per maand is in Bijlage 2 geplot per 5 jaar. Het maand gemiddelde is opgewerkt naar jaar $(=x 12)$ zodat de klasse indeling vergelijkbaar is met die van de jaargemiddelden in bijlage 1 . Donkerrood, de hoogste klasse, wil zeggen dat het vak in die maand gemiddeld in die maand een bevist oppervlak heeft dat groter is dan $0.1 \mathrm{~km}^{2}$.

De tijdserie van de visserijintensiteit rond de monsterpunten binnen en buiten het windpark is weergegeven in figuur 2.

\section{Visserij in en rondom Windpark}

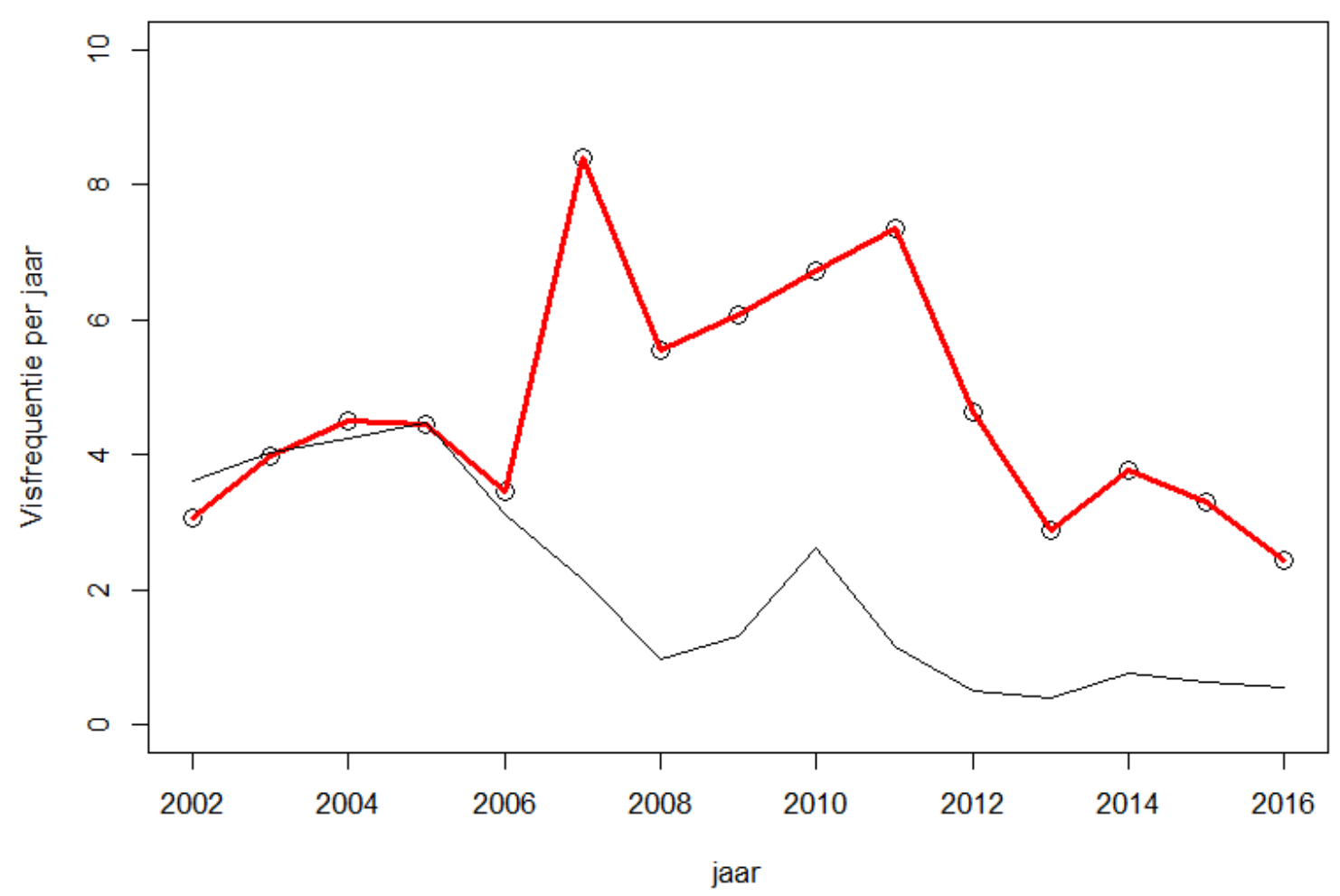

Figuur 2. Visserijintensiteit rondom de meetpunten in en rond het PAWP vanaf 2002. Grijze lijn: binnen het WP en rood: tot $2 \mathbf{~ k m}$ buiten het WP .

Tot en met 2006 verschilt de visfrequentie per jaar binnen of buiten het windparkgebied nauwelijks. Beide gebiedsoppervlakken worden gemiddeld 4 keer per jaar bevist. Daarna neemt de visfrequentie binnen het windparkgebied snel af tot ongeveer 1 keer per jaar in 2008. Na een piek in $2010(2.6 \mathrm{x}$ per jaar) stabiliseert de frequentie op een niveau rond 0.5 keer per jaar.

Buiten het windpark neemt de visfrequentie na 2006 toe tot 6 keer per jaar of meer. Vanaf 2011 daalt de bevissingsfrequentie tot 2.5 keer per jaar in 2016. 


\section{$4 \quad$ Discussie}

Het PAWP ligt buiten de 12 mijlszone waar vissen met grote schepen (motorvermogen $>221 \mathrm{~kW}$ ) is toegestaan maar kleinere Eurokotters zijn ook actief in de omgeving. Dit resulteert in een hoge visserijdruk in (voor 2006) en rondom het gebied. De vloot is het actiefst in de maanden maart tot en met juni.

De algemene dynamiek van de Nederlandse platvisvisserij is ook te zien in - en rond het windpark. De visserijdruk op platvis (schol en tong) is vanaf 2006 gehalveerd. Bovendien is de vlootsamenstelling vanaf 2011 significant veranderd. Een groot deel van het traditionele boomkor vistuig is in 2016 vervangen door pulskor met minder bodemberoering.

De bevissing "binnen" het windpark vindt na 2008 plaats aan de randen. Er zijn in het centrum geen VMS registraties meer waargenomen vanaf 2008. 


\section{Bijlagen}

A:

Visserij-intensiteit 2002 - 2004

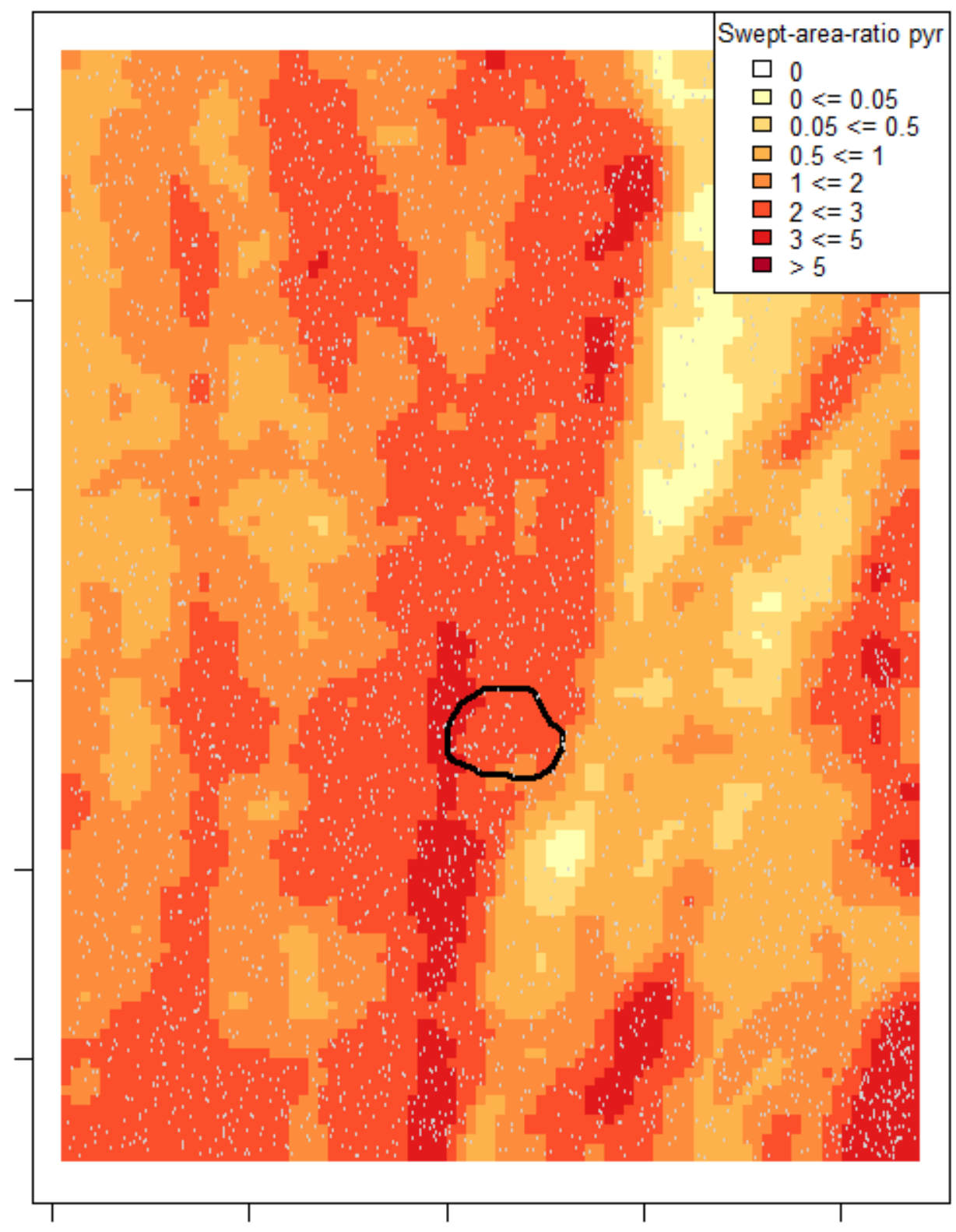




\section{Visserij-intensiteit 2005 - 2006}

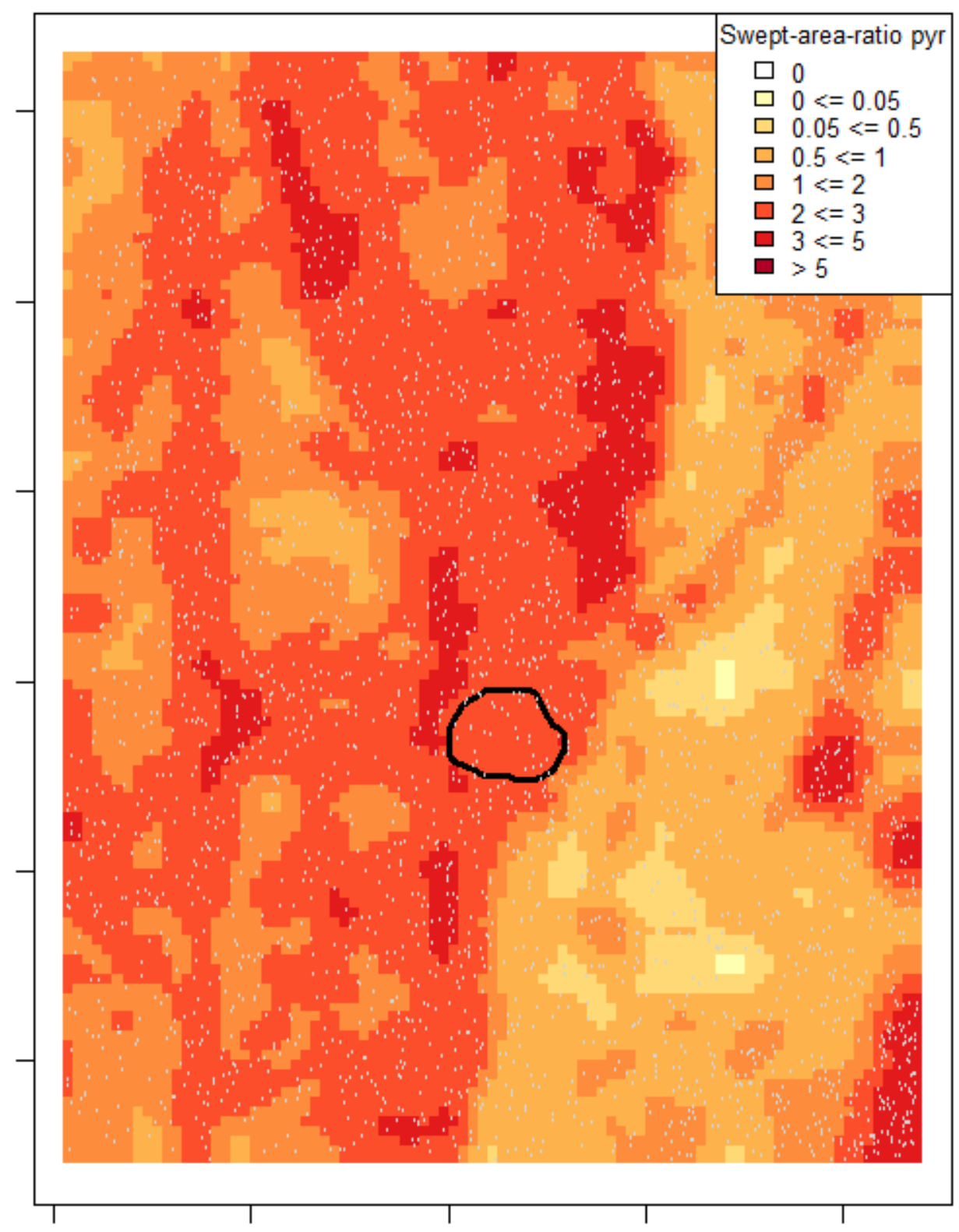




\section{Visserij-intensiteit 2007 - 2008}

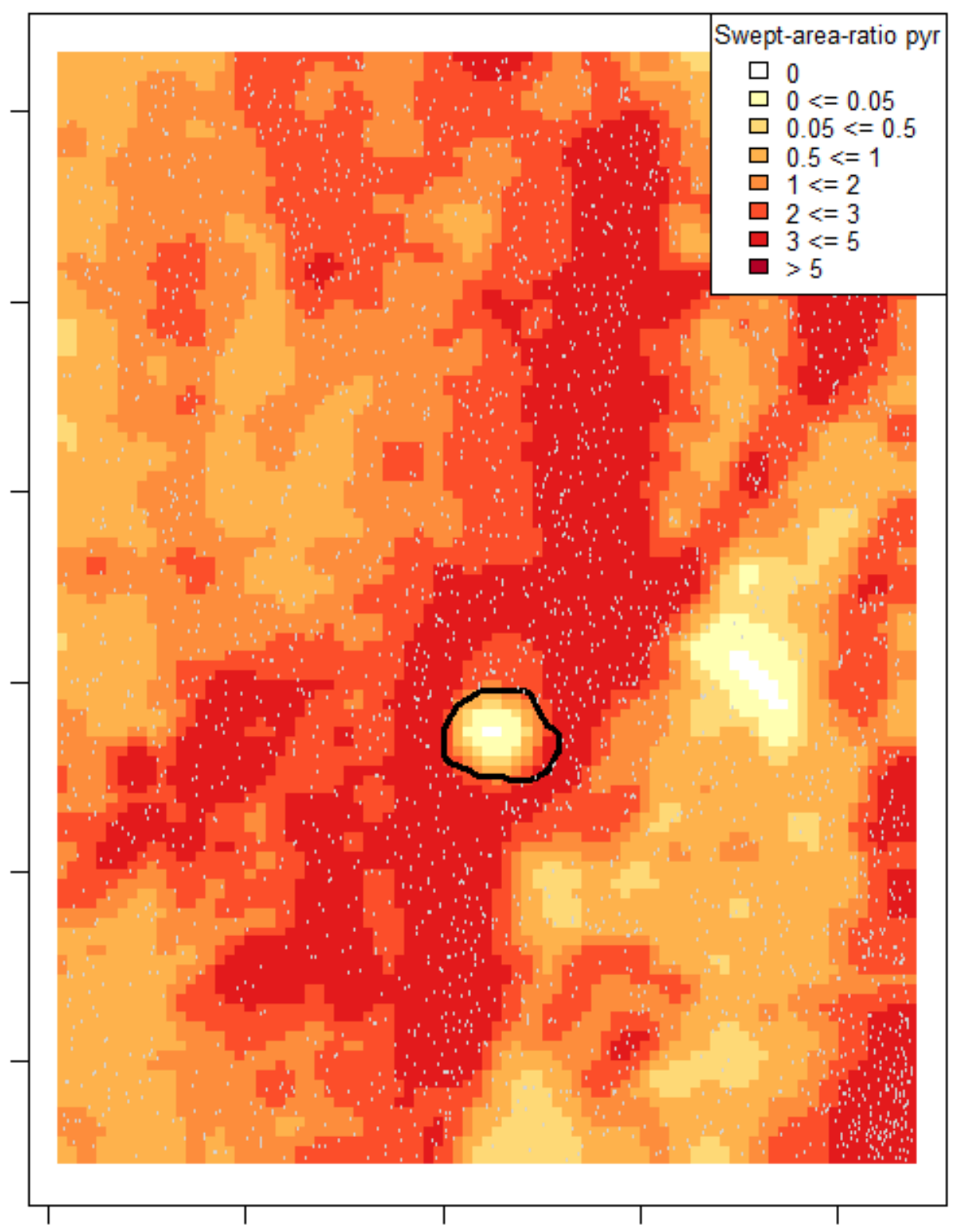




\section{Visserij-intensiteit 2009 - 2010}

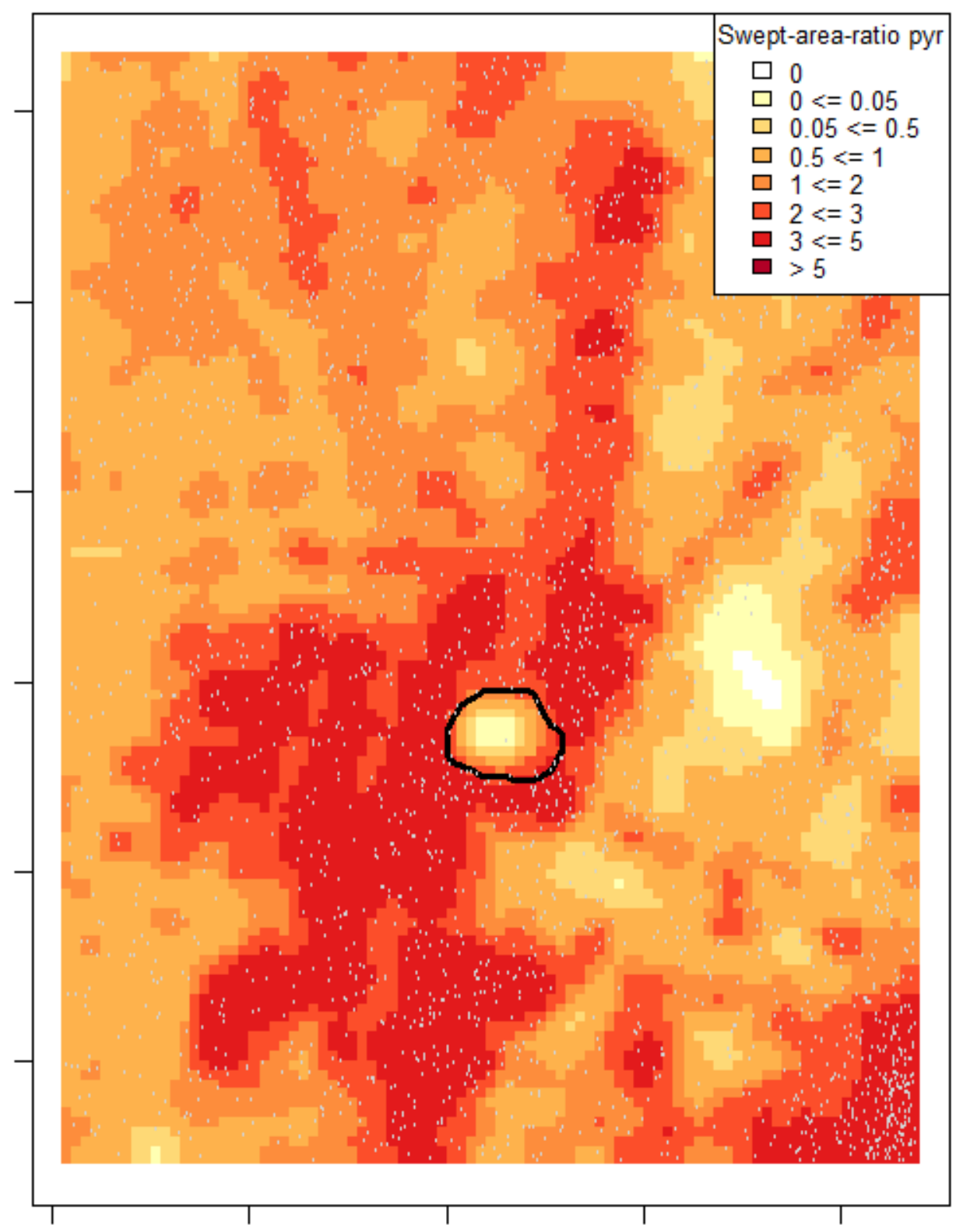




\section{Visserij-intensiteit $2011-2012$}

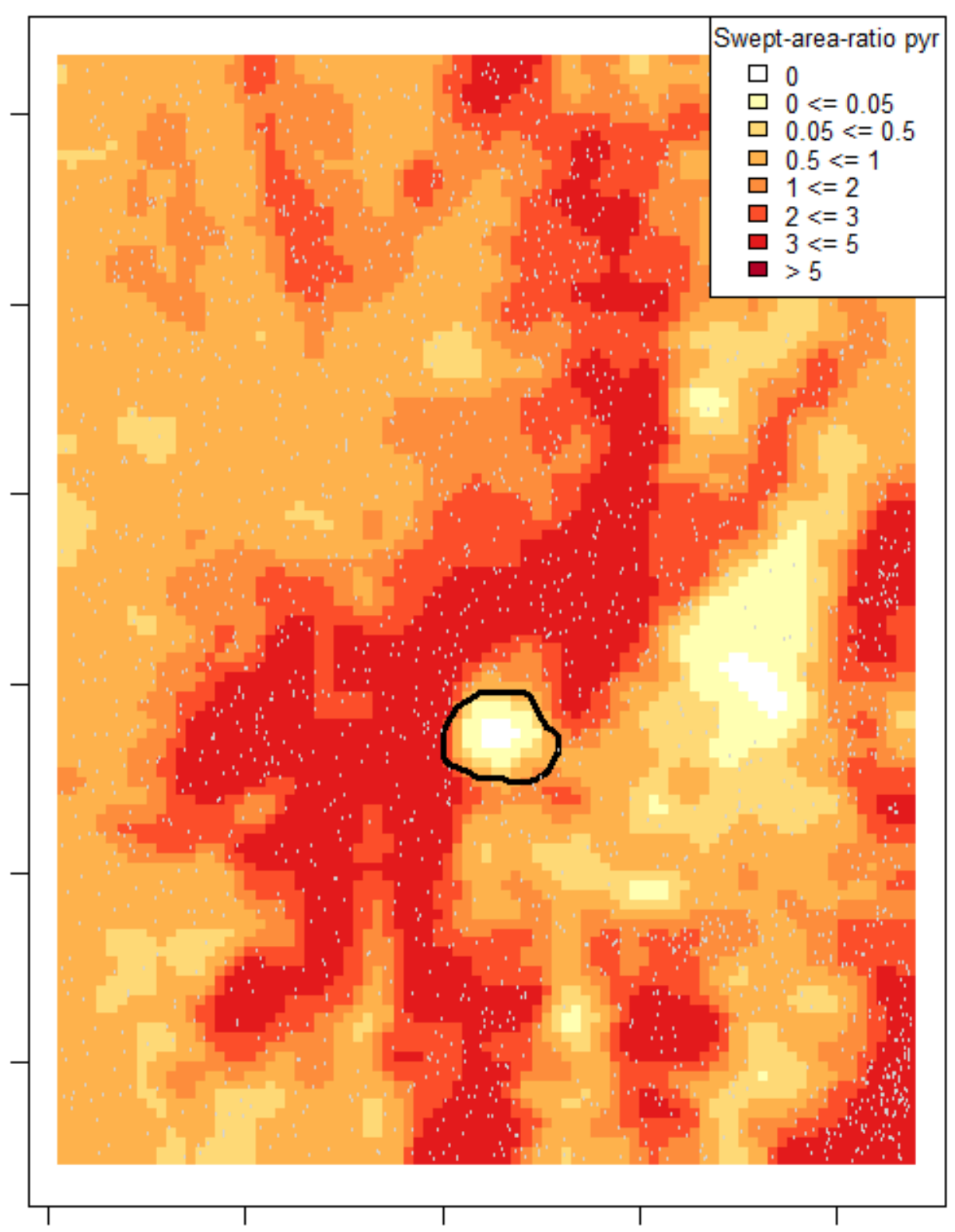




\section{Visserij-intensiteit $2013-2014$}

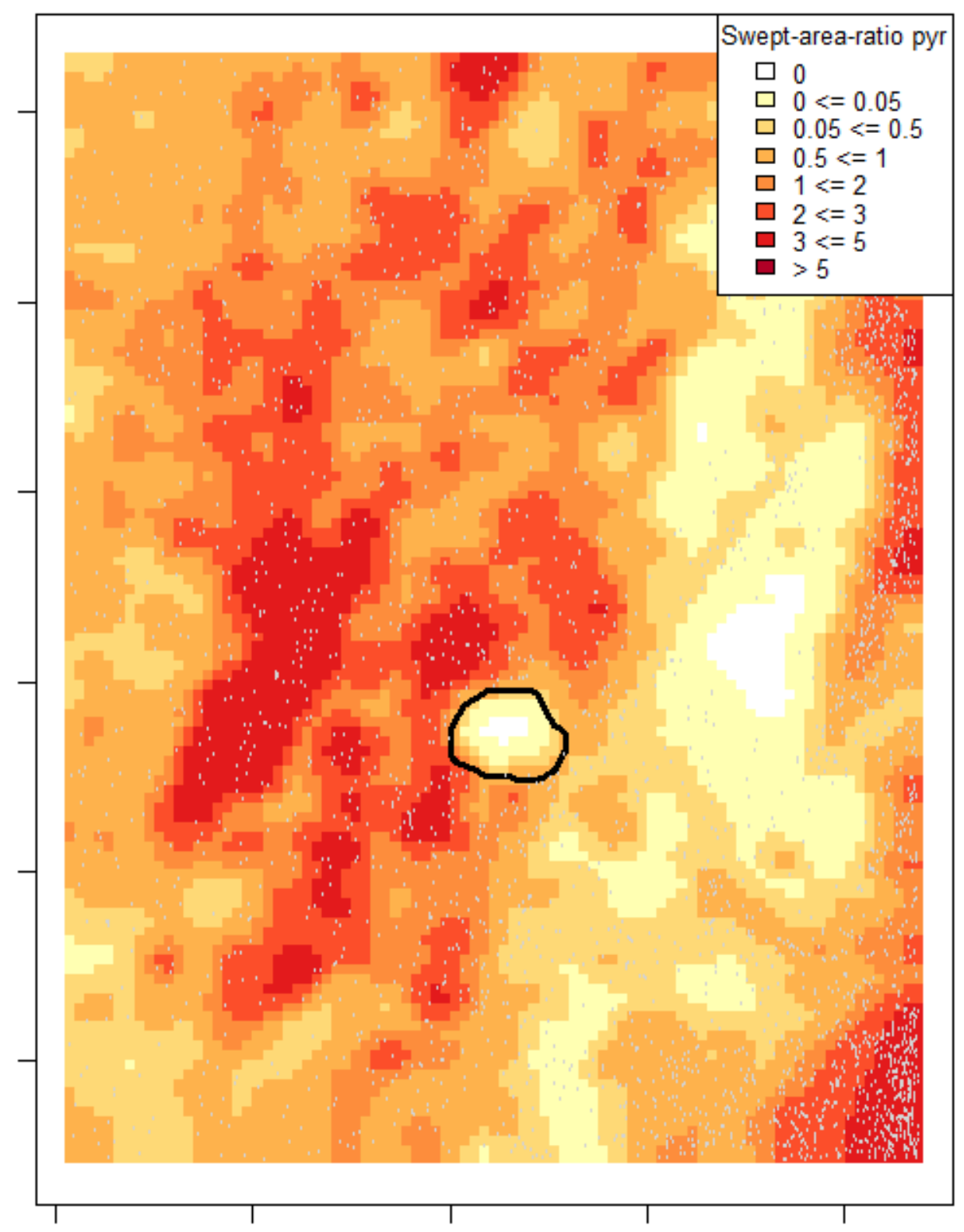




\section{Visserij-intensiteit $2015-2016$}

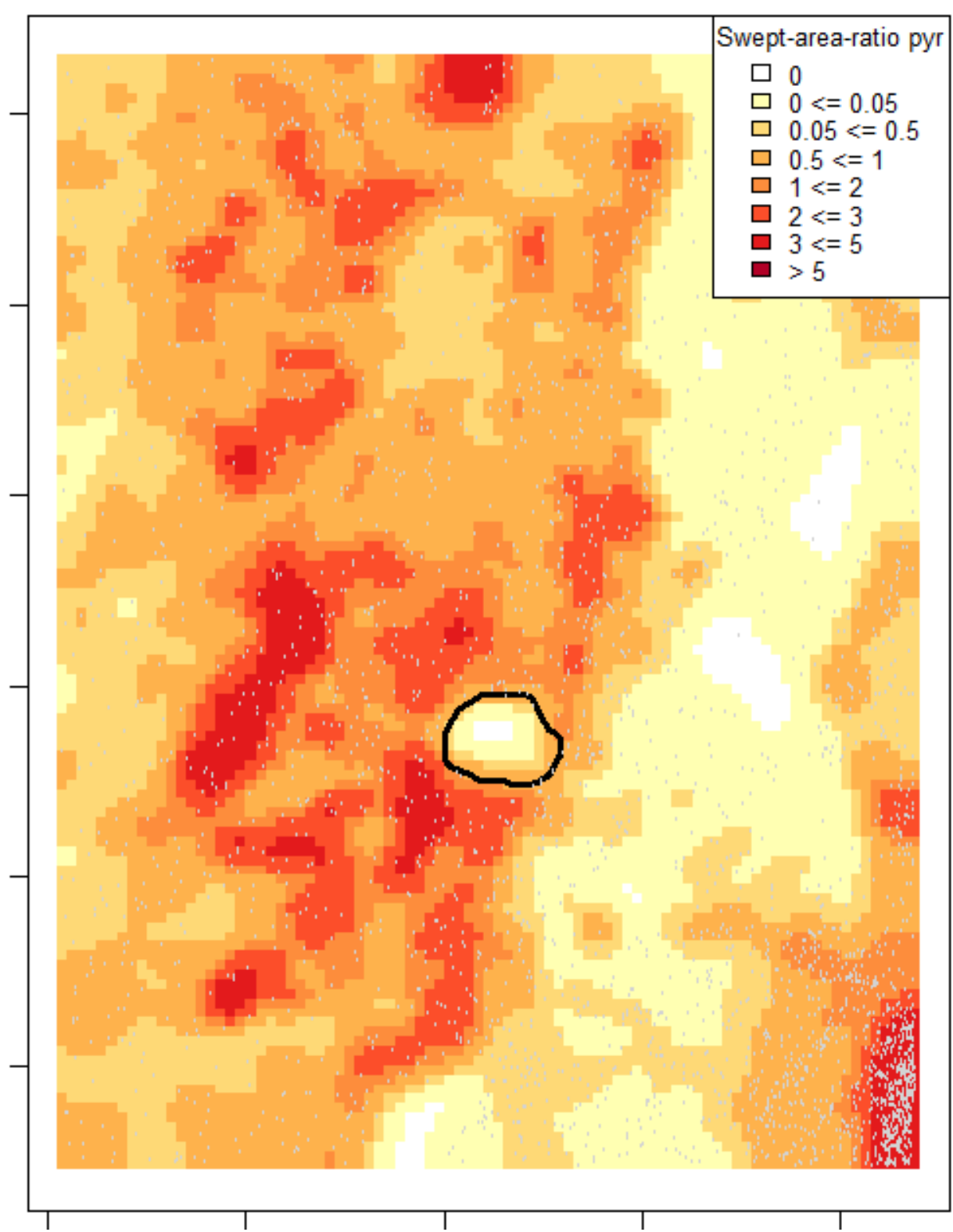

Gemiddelde visserij-intensiteit (Bevist oppervlak per vak van $0.5 \times 0.5 \mathrm{~km}$, ingedeeld in klassen) in en rondom het PAWP van 2002 tot en met 2016. 

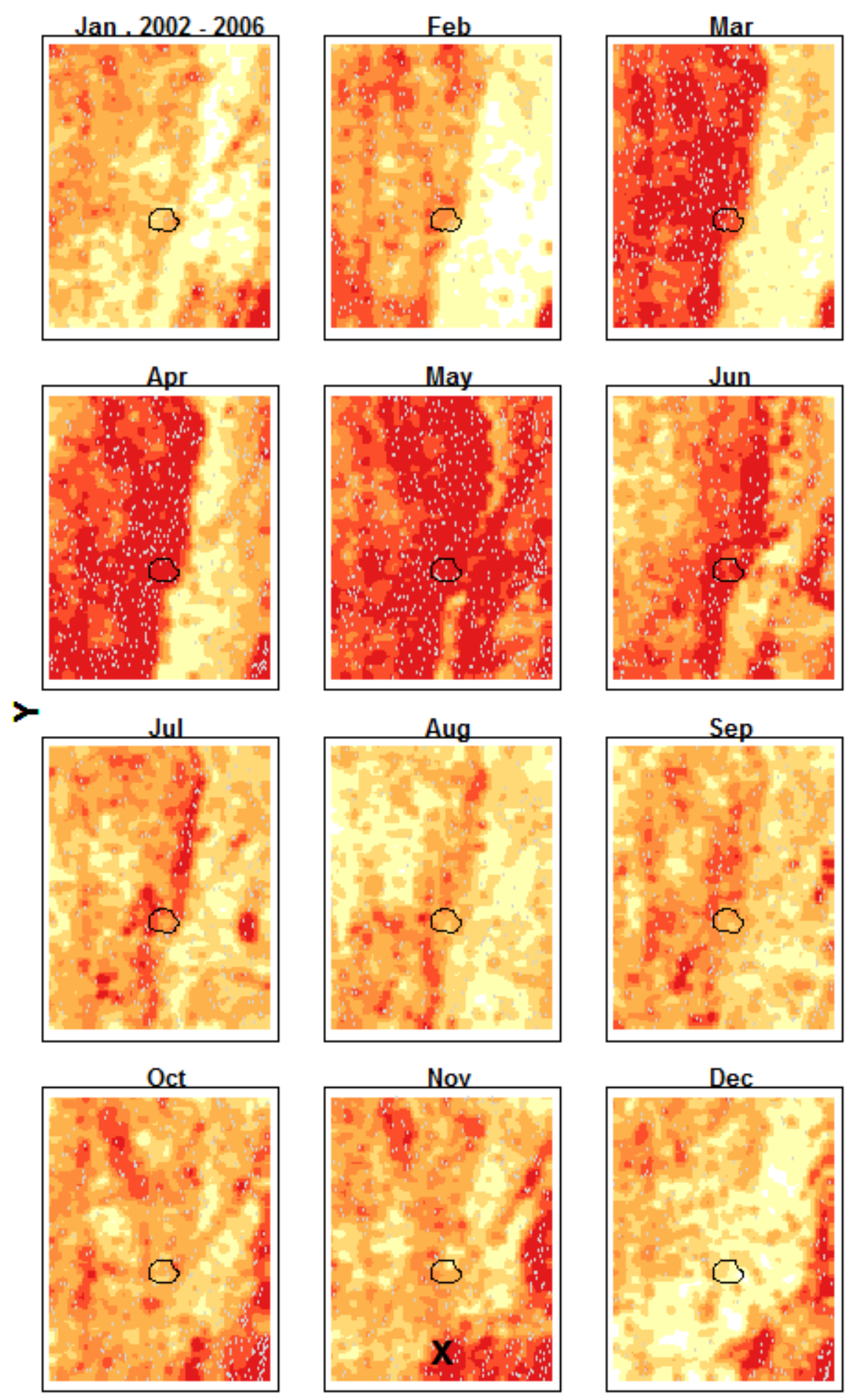

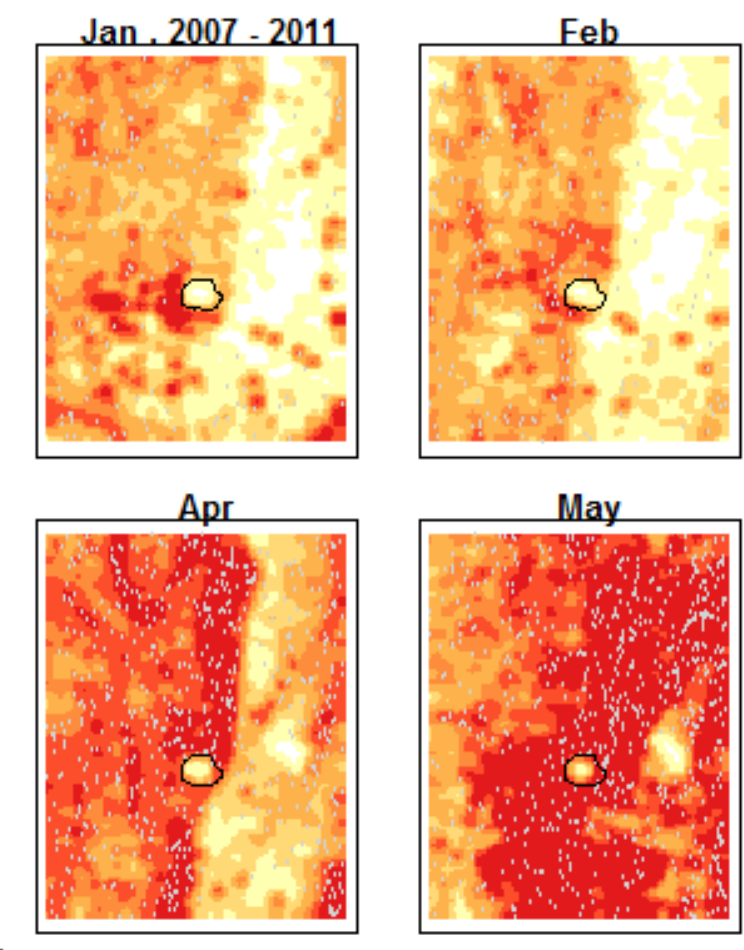

Jul

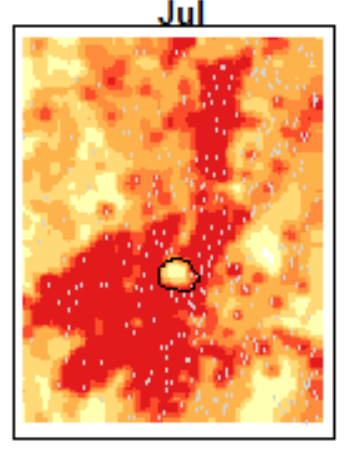

Oct

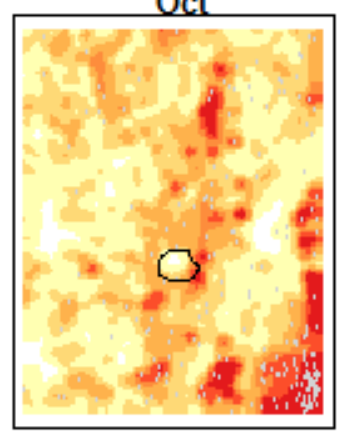

May

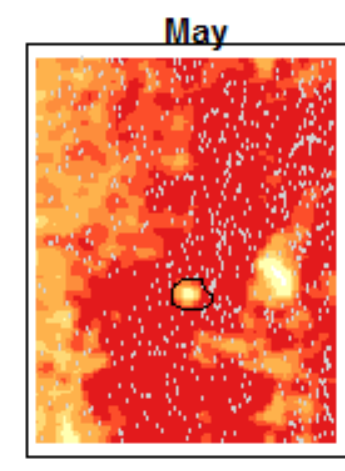

Aug

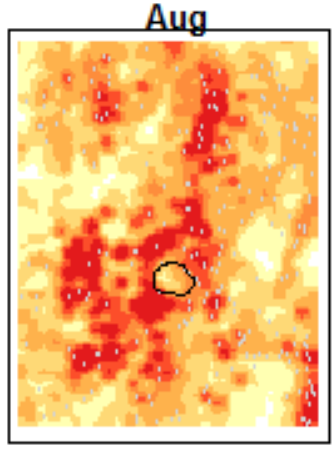

Nov

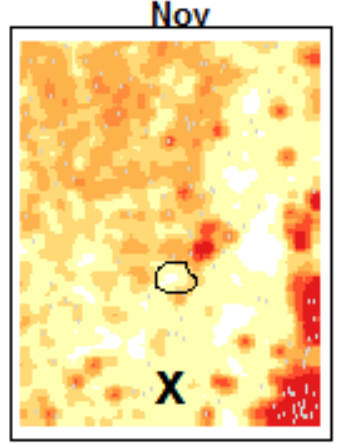

Mar

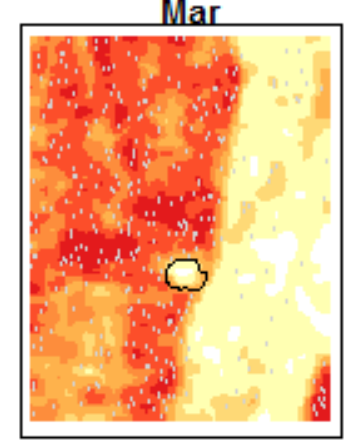

Jun

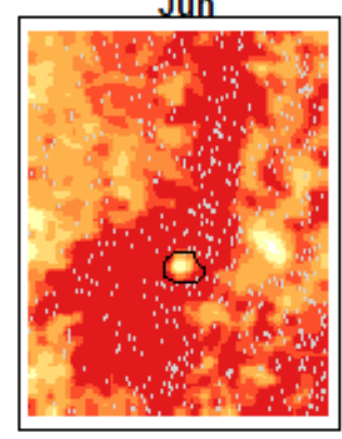

Sep

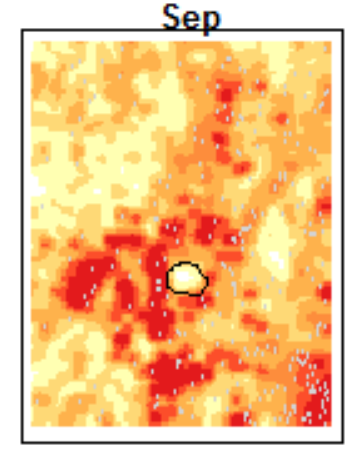

Dec

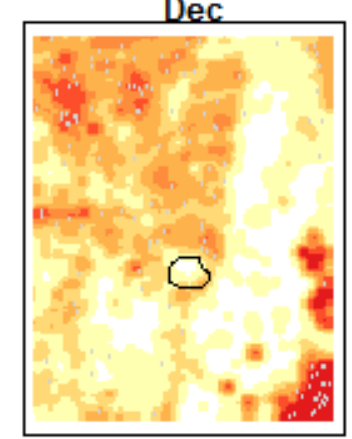



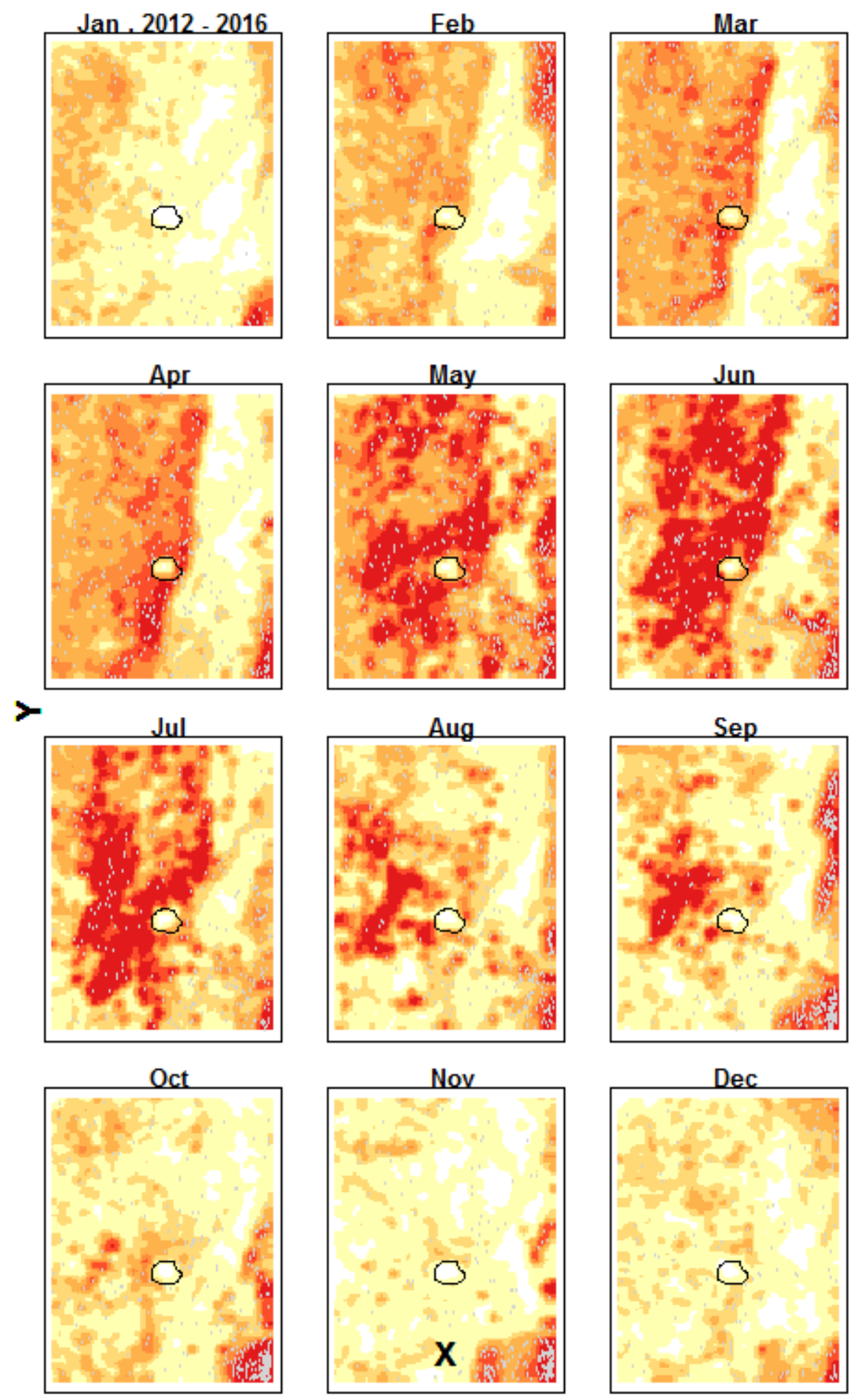

Gemiddelde visserij-intensiteit (Bevist oppervlak per vak van $0.5 \times 0.5 \mathrm{~km}$, ingedeeld in klassen) in en rondom het PAWP per maand voor perioden van 5 jaar van 2002 tot en met 2016 . 


\section{$6 \quad$ Kwaliteitsborging}

Wageningen Marine Research beschikt over een ISO 9001:2008 gecertificeerd

kwaliteitsmanagementsysteem (certificaatnummer: 187378-2015-AQ-NLD-RvA). Dit certificaat is geldig tot 15 september 2018. De organisatie is gecertificeerd sinds 27 februari 2001. De certificering is uitgevoerd door DNV Certification B.V.

Het chemisch laboratorium te IJ muiden beschikt over een NEN-EN-ISO/IEC 17025:2005 accreditatie voor testlaboratoria met nummer L097. Deze accreditatie is geldig tot 1 april 2017 en is voor het eerst verleend op 27 maart 1997; deze accreditatie is verleend door de Raad voor Accreditatie. Het chemisch laboratorium heeft hierdoor aangetoond in staat te zijn op technisch bekwame wijze valide resultaten te leveren en te werken volgens de ISO17025 norm. De scope (L097) met de geaccrediteerde analysemethoden is te vinden op de website van de Raad voor Accreditatie (www.rva.nl). 


\section{Referenties}

Hintzen, N.T.; Coers, A.; Hamon, K. (2013) A collaborative approach to mapping value of fisheries resources in the North Sea (Part 1: Methodology). IJ muiden : IMARES, (Report C001/13) - p. 24 


\section{Verantwoording}

Rapport C091/17

Projectnummer: 4315100056

Dit rapport is met grote zorgvuldigheid tot stand gekomen. De wetenschappelijke kwaliteit is intern getoetst door een collega-onderzoeker en het verantwoordelijk lid van het managementteam van Wageningen Marine Research

Akkoord:

Niels Hintzen

Onderzoeker

Handtekening:

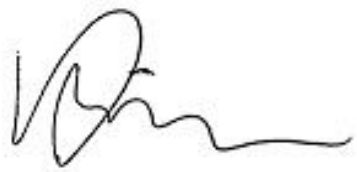

Datum:

12 december 2017

Akkoord:

Drs. J. Asjes

MT lid integratie

Handtekening:

Datum:

12 december 2017 
Wageningen Marine Research

$\mathrm{T}:+31(0) 317480900$

E: marine-research@wur.nl

www.wur.nl/marine-research

Visitors address

- Ankerpark 271781 AG Den Helder

- Korringaweg 5, 4401 NT Yerseke

- Haringkade 1, 1976 CP IJ muiden
Wageningen Marine Research is the Netherlands research institute established to provide the scientific support that is essential for developing policies and innovation in respect of the marine environment, fishery activities, aquaculture and the maritime sector.

\section{The Wageningen Marine Research vision:}

'To explore the potential of marine nature to improve the quality of life.'

\section{The Wageningen Marine Research mission}

- To conduct research with the aim of acquiring knowledge and offering advice on the sustainable management and use of marine and coastal areas.

- Wageningen Marine Research is an independent, leading scientific research institute.

Wageningen Marine Research is part of the international knowledge organisation Wageningen UR (University \& Research centre). Within Wageningen UR, nine specialised research institutes of the Wageningen Research Foundation have joined forces with Wageningen University to help answer the most important questions in the domain of healthy food and living environment. 